\title{
Continuous Decolorization of Acid Blue 62 Solution in an Enzyme Membrane Reactor
}

\author{
Marcin Lewańczuk ${ }^{1}$ - Jolanta Bryjak ${ }^{1}$
}

Received: 20 April 2015 / Accepted: 30 June 2015 /

Published online: 6 August 2015

(C) The Author(s) 2015. This article is published with open access at Springerlink.com

\begin{abstract}
This paper focuses on using an enzyme membrane reactor (EMR) for the effective continuous decolorization of Acid Blue 62 (AB62). The following factors were considered for the effective use of Cerrena unicolor laccase immobilized in the EMR volume: the enzyme was stable in six successive runs in a batch reactor; no aeration was necessary; AB62 and the oxidized products were sorbed onto the membrane but were not rejected; and the enzyme was stable in the EMR system. It is obvious that any continuous process must be predictable, and thus, the objective was to verify the process model experimentally. For this reason, a proper isoenzyme kinetic equation was selected and the parameters were evaluated. The obtained kinetic parameters were used to plan processes and to verify their applicability to long-term AB62 decolorization, and a very good agreement between the calculated and the measured data was obtained. In the main designed continuous decolorization process, the conversion reached $98 \%$ and was stable for 4 days. The membrane reactor with $C$. unicolor laccase appears to be very promising for AB62 decolorization.
\end{abstract}

Keywords Decolorization $\cdot$ Kinetic parameters $\cdot$ Laccase $\cdot$ Membrane bioreactor $\cdot$ Wastewater treatment

\section{Introduction}

In recent years, with the growing concern for clean environment, more attention has been paid to the pollutants generated by textile industry. Many dyes in the wastewater are toxic and potentially carcinogenic; hence, a great number of separation techniques have been developed for treatment of such effluents. The most commonly used are coagulation, flocculation, foam flotation, membrane filtration, and chemical processes $[1,2]$. Physicochemical methods

Jolanta Bryjak

jolanta.bryjak@pwr.wroc.pl

1 Faculty of Chemistry, Department of Bioorganic Chemistry, Wrocław University of Technology, Norwida 4/6, Wrocław, Poland 
require a lot of energy, consume some chemicals, and can generate a substantial amount of precipitate that causes secondary pollution problems and requires additional processing [3]. Enzymatic or microbial dye degradation is regarded as an environmentally friendly, costcompetitive, and simple alternative to chemical decomposition processes [4].

Laccases (benzenediol:oxygen oxidoreductase, EC 1.10.3.2.) attract attention because they oxidize substrates without requiring expensive co-factors (mostly oxidoreductases) or $\mathrm{H}_{2} \mathrm{O}_{2}$ (peroxidases). These enzymes are reactive towards many phenolic and nonphenolic compounds and use dioxygen as the only electron acceptor. Hence, laccases can be used to treat effluents containing phenolic compounds from many industrial sectors, including textile one. These treatments are based on cross-coupling reactions, homo- or hetero-polymerization, or simple degradation [5]. Laccases are often used to decolor many dyes (see reviews [6, 7]) including anthraquinone ones, the most important subclass of carbonyl dyes. Unfortunately, most of these dyes are toxic, carcinogenic, or mutagenic and they are resistant towards light or oxidizing agents [8]. To remove them, several physicochemical [9-11] or biological [12-16] methods have been applied [8, 17, 18]. It seems that the interesting alternative for dye decolorization by biocatalyst is the application of a continuous system with a semipermeable membrane to separate products and an enzyme from a reaction mixture.

An enzymatic membrane reactor (EMR) can operate in many different configurations that depend on the reaction type and enzyme properties [19]. The most frequently used mode is a membrane reactor with a soluble form of enzyme immobilized in the volume of reactor. The used ultrafiltration (UF) membrane with a 5-10-kDa-molecular-weight cutoff keeps an enzyme in reactor volume and does not allow it to be washed out (Fig. 1). EMRs have many advantages, among them one can point at the most important: (i) a membrane successfully stops enzymes; (ii) no loss of an enzyme is observed that is common in other immobilization methods; (iii) for unstable enzymes, the biocatalyst can be refreshed easily; (iv) homogeneous reactions are unaffected by the diffusion resistance; and (v) the system can be easily scaled-up [20]. On the other side, EMR applications have several limitations: (i) membrane fouling that can limit the filtration rate; (ii) the request for reactants to be soluble; (iii) the request for biocatalyst to be stable in the process conditions; (iv) the request for membrane to reject the enzyme completely but be permeable to product(s); and (v) the membrane material should be stable in the process conditions and cannot react with any mixture component [20]. The use of laccase in EMR designated for dye decolorization seems to be a very promising but not so popular [21-23] approach. Moreover, the studies on decolorization modeling that take into account enzyme kinetics were rarely presented [24, 25].

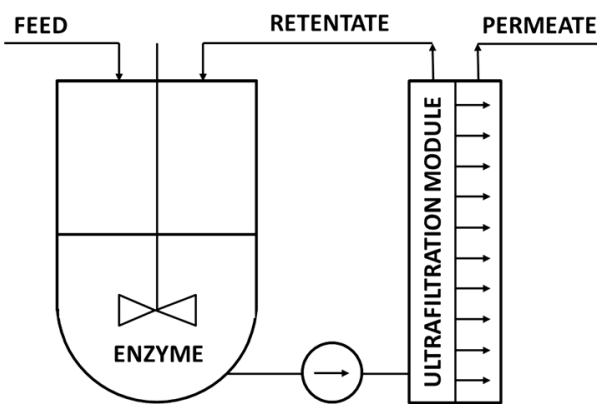

Fig. 1 Set-up of a membrane reactor 
The present investigation focuses on the decolorization of Acid Blue 62 (AB62) in EMR. AB62 was selected as the products of its oxidation by laccases are well known and they are less toxic than AB62 [26]. The process was performed using extracellular laccase from Cerrena unicolor because this biocatalyst can be produced without any inducers and its purification is cost effective [27]. Moreover, the decolorization of AB62 by this laccase does not require expensive mediators. A few physical and biological methods have been tested for AB62 decolorization [28-31], but to the best knowledge of the authors, there are no reports on the use of EMR. The present paper focuses on the enzyme stability, substrate/product sorption onto membrane, reaction kinetics, process modeling, and the model validation in long-term AB62 decolorization with soluble laccase immobilized in EMR.

\section{Materials and Methods}

\section{Materials}

AB62 was donated by Boruta-Zachem (Poland). Lowry's reagent and 2,2-azino-bis(3ethylbenzthiazoline-6-sulfonate) sodium salt (ABTS) were supplied by Sigma-Aldrich. Other reagents of analytical grade were purchased from POCH (Poland).

\section{Production of Laccase and Enzyme Activity Assay}

The wood-rotting fungus C. unicolor (Bull. ex. Fr.) Murr, No. 139 was obtained from the culture collection of the Department of Biochemistry, University of Lublin (Poland). The microorganism cultivation, laccase production, and purification were performed according to methods described earlier [27].

The progress of the dye conversion was followed using a spectrophotometric method in which the UV-Vis spectra from 220 to $800 \mathrm{~nm}$ were recorded for multiple time points. The change of absorbance (Fig. 2) was consistent with the data obtained by other researchers working with white-rot fungi [32-34] or purified laccases [26, 35]. The quantitative measurements of the substrate concentration were made at $637 \mathrm{~nm}$ (Fig. 2, solid line), in the region of insignificant absorbance of the reaction product (Fig. 2, dashed line). The substrate

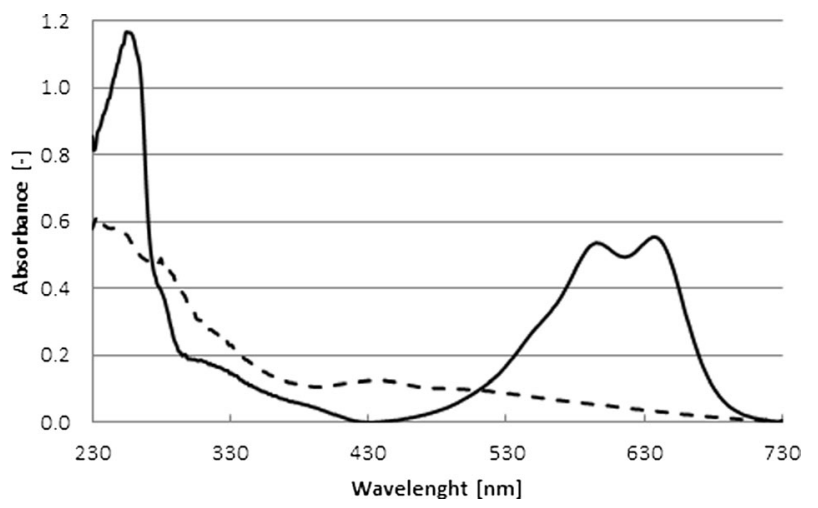

Fig. 2 AB62 spectra $(113.6 \mu \mathrm{M})$ before (solid line) and after (dashed line) decolorization with laccase 
concentrations were calculated from the linear region of the calibration curve $\left(R^{2}=0.998\right)$. A spectrum of the product solution was recorded after $12 \mathrm{~h}$ incubation of the substrate with laccase $\left(R^{2}=0.993\right.$ for the calibration curve).

Laccase activity towards AB62 was measured as absorbance $(637 \mathrm{~nm})$ decrease in initial reaction time (linear dependence). One activity unit $\left(\mathrm{U}_{\mathrm{AB} 62}\right)$ was defined as the amount of protein that caused a $2.5-\mu \mathrm{M}$ decrease in the dye concentration per minute under reaction conditions ( $\mathrm{pH} 5.3,0.1 \mathrm{M}$ phosphate-citrate buffer, $30{ }^{\circ} \mathrm{C}, 113.6 \mu \mathrm{M}$ initial substrate concentration). The enzyme preparation used through this study had a specific activity of $11,000 \mathrm{U} \mathrm{mg}^{-1}$ protein. The protein concentration was assayed by Lowry's method [36], using bovine serum albumin as a standard. Measurements of laccase activity and protein concentration were done in triplicate $( \pm 1.5$ and $\pm 2.6 \%$, respectively).

\section{Enzyme Activity and Stability in pH}

The optimum $\mathrm{pH}$ was evaluated in the range of $4.7-6.5$ at $30^{\circ} \mathrm{C}$. No color change was noted in control probes with the dye solutions of different $\mathrm{pH}$ without laccase. The value obtained in $\mathrm{pH}$ 5.3 was set as $100 \%$.

The $\mathrm{pH}$ stability was determined by incubating $\left(30^{\circ} \mathrm{C}\right)$ the sample at the given $\mathrm{pH}$ (ranging from 4.5 to 6.7 ) for 5 and $36 \mathrm{~h}$. The $\mathrm{pH}$ of the solution was then adjusted to 5.3, and the preparation was left for $1 \mathrm{~h}$ to equilibrate and then its activity was measured (irreversible inactivation).The activity values measured just before incubation were set as $100 \%$.

All measurements were carried out in triplicate $( \pm 2.4 \%)$.

\section{AB62 Decolorization in a Batch Reactor}

AB62 solution $(0.05 \mathrm{~mL}, 68.2 \mathrm{mM}$, final dye concentration $113.6 \mu \mathrm{M})$ was added to the enzyme solution in $0.1 \mathrm{M}$ phosphate-citrate buffer $\left(30 \mathrm{~mL}, 3 \mathrm{U}_{\mathrm{AB} 62} \mathrm{~mL}^{-1}\right)$. The absorbance decrease $\left(637 \mathrm{~nm}, 30{ }^{\circ} \mathrm{C}\right)$ was measured to control the decolorization process. The reaction was monitored (20-s intervals) up to the substrate depletion (the stable absorbance level). The activity of laccase was calculated on the base of initial linear dependence of absorbance vs time. The value obtained in the first process was set as $100 \%$. Next, five consecutive portions of the substrate were added after substrate depletion.

The influence of oxygen consumption on the enzyme activity was checked by monitoring the oxygen concentration using a luminescent dissolved oxygen probe (LDO10101, Hach Lange).

\section{Membrane Start-Up}

Studies were performed at $30{ }^{\circ} \mathrm{C}$ in a Labscale ${ }^{\mathrm{TM}} \mathrm{TFF}$ System (Millipore, Bedford, USA), comprising a $500-\mathrm{mL}$ reservoir stir base, retentate valve, pressure gauges, and a diaphragm pump, and with a Pellicon ${ }^{\circledR}$ XL module (Millipore) equipped with Biomax-5 membrane with $50 \mathrm{~cm}^{2}$ of filtration area. The Biomax-5 membrane is made of polyethersulfone, and its molecular weight cutoff is $5 \mathrm{kDa}$. Before the experiments, the UF unit with the Pellicon module was rinsed according to the supplier's procedure. Pure water and $0.1 \mathrm{M}$ phosphatecitrate buffer ( $\mathrm{pH}$ 5.3) fluxes were measured prior to processing $\left(1.4910^{-5} \pm 1.6710^{-7}\right.$ and $1.3910^{-5} \pm 1.0010^{-7} \mathrm{~m}^{3} \mathrm{~s}^{-1} \mathrm{~m}^{-2}$, respectively, for transmembrane pressure (TMP) $0.137 \mathrm{MPa})$. 
After completion of the experiments, the system was cleaned according to the manufacturer's specification [27]. The cleaning process was kept running until the permeate flux was not lower than $95 \%$ of its initial value.

\section{Studies on Membrane Separation Properties in the Presence of the Reactants}

To test the separation/sorption properties of the membrane in the presence of reactants, the reservoir was filled with $50 \mathrm{~mL}$ of the tested solution, and the TMP was set at $0.137 \mathrm{MPa}$. The system was used in diafiltration mode. Permeate samples were collected at various times. After the diafiltration and retentate drainage, $50 \mathrm{~mL}$ of the buffer was added to the system. The permeate and retentate were recirculated without TMP for $30 \mathrm{~min}$ to wash the compounds that were loosely bound to the membrane. The retentate from this step was named the wash-out solution. The feed, wash-out, retentate, and permeate samples were analyzed.

The above procedure was applied using $50 \mathrm{~mL}$ of AB62 solution $(113.6 \mu \mathrm{M})$ continuously fed into the membrane reactor (averaged permeate flux was $1.1410^{-5} \pm 2.3310^{-7} \mathrm{~m}^{3} \mathrm{~s}^{-1} \mathrm{~m}^{-2}$ ). The absorbance was monitored at $637 \mathrm{~nm}$ in all samples. To test membrane in the presence of the reaction product, $2 \mathrm{~L}$ of the substrate solution was incubated at room temperature with laccase $\left(2 \mathrm{U}_{\mathrm{AB} 62} \mathrm{~mL}^{-1}\right)$ for $12 \mathrm{~h}$. Afterwards, the decolorized solution was used as a feed (averaged permeate flux was $9.3310^{-6} \pm 4.6710^{-7} \mathrm{~m}^{3} \mathrm{~s}^{-1} \mathrm{~m}^{-2}$ ), and the absorbance was monitored at $490 \mathrm{~nm}$.

To determine the amount of enzyme sorbed on all parts of the EMR system, the reservoir was filled with $50 \mathrm{~mL}$ of laccase solution $\left(5 \mathrm{U} \mathrm{mL}^{-1}\right)$. The retentate was recirculated for $180 \mathrm{~min}$, and the permeate was turned back to retentate. The retentate samples were collected in specified time intervals and analyzed for laccase activity.

\section{Kinetic Studies}

The initial rates of AB62 decolorization was measured by monitoring the absorbance decrease at $637 \mathrm{~nm}$ using $1.95 \mathrm{~mL}$ of buffered dye solution with AB62 concentrations changing from 12.5 to $250 \mu \mathrm{M}$ and with $0.05 \mathrm{~mL}$ of laccase solution with a final protein concentration of 290 and $408 \mu \mathrm{g} \mathrm{L}^{-1}$ (3.2 and $4.5 \mathrm{U}_{\mathrm{AB} 62} \mathrm{~mL}^{-1}$ ). All measurements were done at least in triplicate $( \pm 2.1 \%)$. The Michaelis and rate constants were estimated by nonlinear regression by means of OriginPro 9 software.

\section{Continuous AB62 Decolorization in EMR and the Process Modeling}

Continuous decolorization of AB62 was performed at $30{ }^{\circ} \mathrm{C}$, using a buffered 113.6- $\mu \mathrm{M}$ solution of AB62 as feed. The reactor volume was filled with $50 \mathrm{~mL}$ of laccase solution (1.5 and $\left.12 \mathrm{U}_{\mathrm{AB} 62} \mathrm{~mL}^{-1}\right)$. Decolorization was performed using selected permeate fluxes $\left(5.6710^{-6}\right.$ and $4.6710^{-6} \mathrm{~m}^{3} \mathrm{~s}^{-1} \mathrm{~m}^{-2}$ ) which were controlled by changing the TMP. The permeate samples $(50 \mathrm{~mL})$ were collected, and the absorbance was monitored at $637 \mathrm{~nm}$. The steady-state conditions were confirmed by specifying the same absorbance values in permeate in three consecutive analysis in 0.5 -h intervals.

A continuous operation in a stirred tank reactor was modeled for the following assumptions towards the system: the system runs in a continuous production mode; there is no concentration gradient with respect to the location (effluent concentrations 
are equal to reactor concentrations); the reaction rate $(r)$ in the steady state is stable; the reactor is well-stirred; the reactor keeps constant volume $(V r)$ due to equal inlet and outlet fluxes $(\dot{V})$; and steady state is reached after start-up period (usually, it takes 4-5 times of the residence time, $\tau$ ), where

$$
\tau=\frac{V r}{\dot{V}}
$$

Since at steady state the rate of accumulation is zero, the general component balance for a well-mixed continuous tank reactor has a following form [37]:

$$
0=\dot{V} \cdot C_{\mathrm{S} 0}-\dot{V} \cdot C_{\mathrm{S}}+V_{r} \cdot r
$$

where $C_{\mathrm{S} 0}$ and $C_{\mathrm{S}}$ are the initial substrate concentration and substrate concentration in a reactor at steady state, respectively.

The equation predicts that the reaction causes a depletion of substrate and that the reaction rate at steady state can be obtained from Eq. (3):

$$
r=-\frac{\left(C_{\mathrm{S} 0}-C_{\mathrm{S}}\right)}{\tau}
$$

However, using the Michaelis-Menten approach, the reaction rate from Eq. (4) can be an equivalent of formula (3) at steady state:

$$
r=\frac{k_{\mathrm{cat}} \cdot C_{\mathrm{E}} \cdot C_{\mathrm{S}}}{K_{\mathrm{m}}+C_{\mathrm{S}}}
$$

where $k_{\mathrm{cat}}$ is the rate constant, $C_{\mathrm{E}}$ is the enzyme concentration, and $K_{\mathrm{m}}$ is the Michaelis constant.

Hence, the model can be used to find the system dynamics and to calculate the steady-state values. It must be underlined that the modeling of a membrane-assisted continuous-stirred tank reactor is substantially the same with an assumption that a membrane is a physical barrier only, suitable for the retention of an enzyme.

\section{Results and Discussion}

\section{Laccase Stability}

To increase C. unicolor laccase potential applications, AB62 decolorization was performed without any natural or synthetic mediators, and the enzyme preparation was only partly purified by means of micro- and ultrafiltration [27].

The most important process parameters are influence of $\mathrm{pH}$ and temperature on enzyme activity and enzyme conformational stability. In the case of laccase, its temperature profile and thermal stability were tested previously [38], and it was shown that $30{ }^{\circ} \mathrm{C}$ is the very good compromise between the reactivity and the stability. Taking into account $\mathrm{pH}$ influence, it must be tested in the presence of any given substrate. As seen from Fig. 3, the highest rate of AB62 decolorization is noted in $\mathrm{pH} 5.3$, whereas stability is perfect in a more neutral $\mathrm{pH}$ but at the cost of reactivity. Thus, $\mathrm{pH} 5.3$ was selected that provides the highest activity and satisfactory 


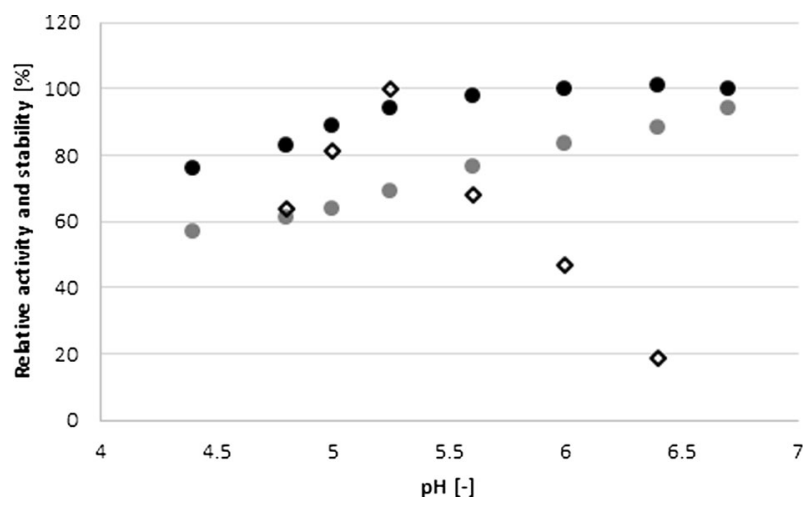

Fig. 3 Effect of $\mathrm{pH}$ on $\mathrm{AB} 62$ decolorization by laccase (white diamond) and on the enzyme stability after 5 (black circle) and $36 \mathrm{~h}$ (gray circle) of incubation in the buffer

stability. Interestingly, Michniewicz et al. [35] showed a maximum AB62 decolorization efficiency around $\mathrm{pH} 3.5$ in the case of laccase from $C$. unicolor but originated from different strains (137).

The effective use of laccase immobilized in the EMR volume for dye decolorization depends on sufficient enzyme stability in the processing conditions. To test the C. unicolor laccase stability in the presence of the substrate and reaction products, six successive batch processes were run in a well-stirred reactor. A fresh substrate was added after the depletion of the previous dose that was manifested as a constant minimal absorbance level (Fig. 4, gray solid line). During these measurements, the laccase activity remained almost the same, and thus, one can conclude that the enzyme is not inactivated by the substrate and/or reaction products and can be used in EMR.

Laccases catalyze the oxidation of a wide range of substrates, and this phenomenon is coupled to the reduction of molecular oxygen to water. Thus, the rate of many reactions can be limited by oxygen consumption. For that reason, the oxygen concentration was monitored (Fig. 4, dotted line) in the process, and the collected results indicated that oxygen consumption

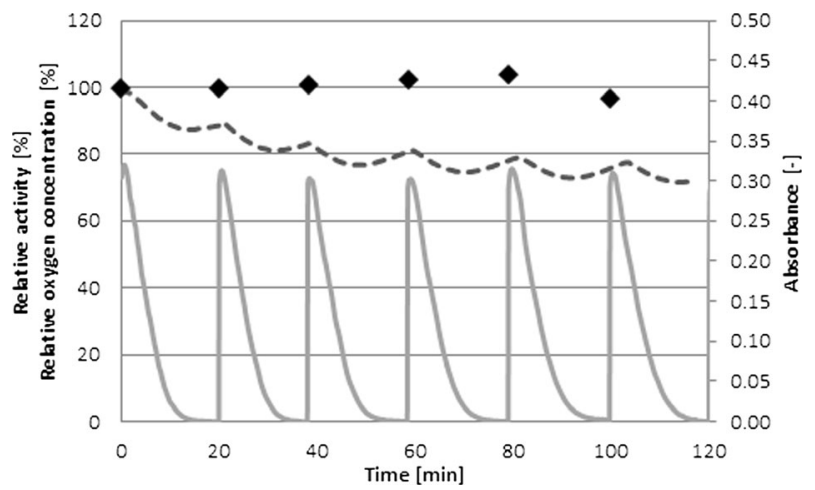

Fig. 4 Repeated batch decolorization $(637 \mathrm{~nm})$ of AB62 $(113.6 \mu \mathrm{M})$ using native laccase $\left(3 \mathrm{U}_{\mathrm{AB} 62} \mathrm{~mL}^{-1}\right)$ at $\mathrm{pH}$ 5.3 and $30^{\circ} \mathrm{C}$. Solid line absorbance after baseline correction, black diamond laccase activity, dashed line oxygen concentration 
should not significantly affect AB62 decolorization. This finding reduces the request for an additional aeration of the reaction mixture for planned processes in EMR.

\section{Sorption of Laccase, AB62, and Products on the Membrane in the EMR Set-Up}

The complete retention of laccase by the polyethersulfone membrane with a molecular weight cutoff of $5 \mathrm{kDa}$ was demonstrated in our previous work [39]. The objective of the present work was to quantify the formation of sorption and/or polarization layer of the enzyme, substrate, and products. In the case of laccase, the activity in the retentate was analyzed in a system, in which the permeate was returned into retentate (Fig. 5a, black points). The decrease of enzyme activity within the first 15 min of the process was observed. This decrease can be attributed to the sorption of protein molecules onto either the system surface or the membrane. Unfortunately, the highly active preparation made it difficult to assay the protein concentration, and the
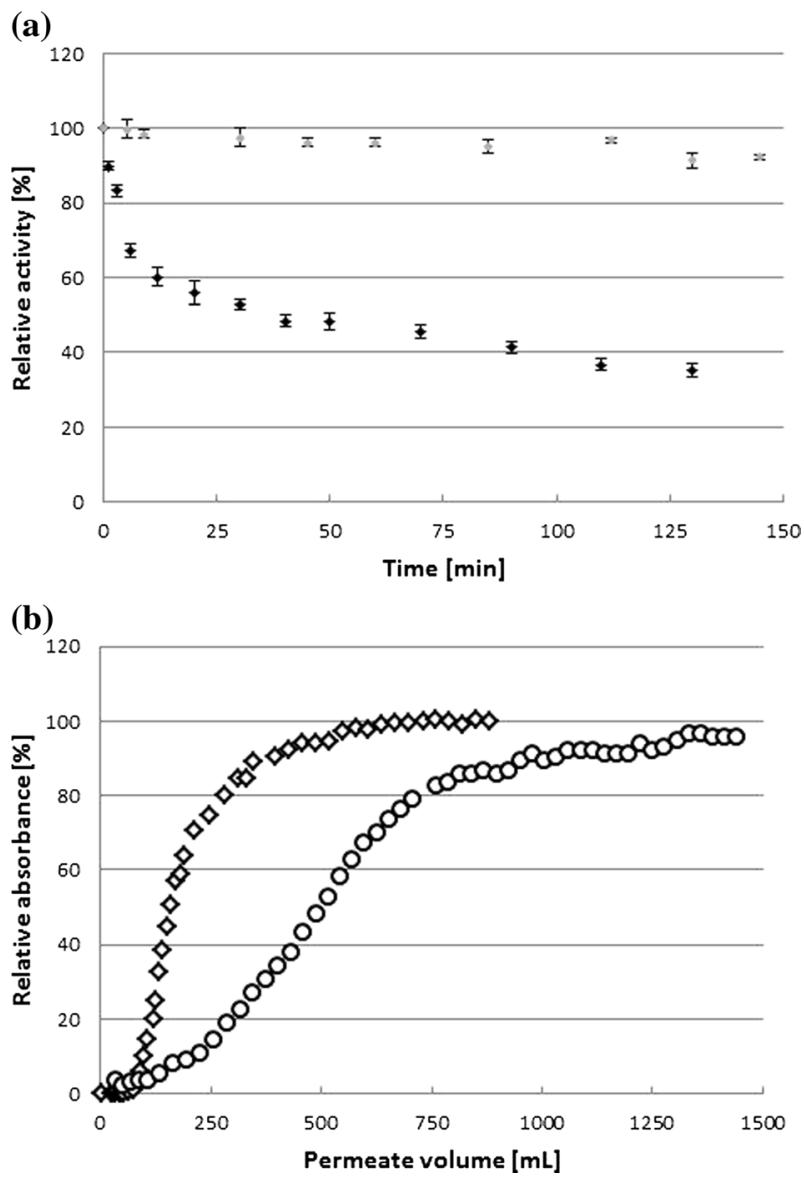

Fig. 5 a Laccase activity in the retentate during the retentate and permeate recirculation in the EMR (black diamond) and during incubation in a stirred tank reactor (black circle). Conditions: $\mathrm{pH} 5.3 ; 30{ }^{\circ} \mathrm{C} ; 100 \mathrm{rpm}$; $0.137 \mathrm{MPa}$, laccase concentration of $5 \mathrm{U} \mathrm{mL}^{-1}\left(453 \mu \mathrm{g} \mathrm{L}^{-1}\right)$. b Absorbance in the permeate during membrane tests using AB62 (white diamond; $637 \mathrm{~nm}$ ) or oxidized AB62 (white circle; $490 \mathrm{~nm}$ ) relative to the feed solution. Tests were performed in diafiltration mode at a transmembrane pressure of $0.137 \mathrm{MPa}, \tau=13.9 \mathrm{~min}, \mathrm{pH} 5.3,30{ }^{\circ} \mathrm{C}$ 
evaluation of the enzyme activity was the only possible way to monitor the sorption phenomenon. In such situation, laccase inactivation process could not be excluded. Therefore, the change in laccase activity with time in a stirred batch reactor was evaluated (Fig. 5a, gray points) and used as a control experiment. The perfect laccase stability in the batch test suggested that the loss of enzyme activity in the EMR was caused mostly by sorption than by the enzyme inactivation. Similar results were obtained previously when a $5-k D a$ membrane was tested for laccase retention in a continuous mode [39]. In that case, the loss of approximately $18 \%$ of the enzyme activity was noted during the first $20 \mathrm{~min}$ of the pre-conditioning, and after that, the activity balance $(95.4 \%$; the sum of total activity in retentate, permeate, and wash-out solution in respect to initial activity) showed almost no activity loss.

Sorption of the enzyme on the membrane surface can be regarded as a serious drawback. Most likely, part of the protein could adsorb in an unfavorable orientation with the active center of the enzyme directed towards the membrane surface, blocking access of substrate [40]. However, sorption of the enzyme, that is still active, onto the membrane can cause a local enzyme concentration increase, making it possible for the substrate to be converted to the product just before leaving a reactor space. However, it was expected that the enzyme sorption onto the membrane could be responsible for lower substrate conversion.

It is obvious that the membrane used in EMR must be permeable to the product; in contrast, this requirement is not as obvious for the substrate. Taking these requests into account, the possibility for rejection of AB62 or its oxidized product was tested (Fig. 5b). Surprisingly, at the very beginning of the test, neither reactant was visible in the permeate, although $50 \mathrm{~mL}$ of substrate or reaction product was poured into the EMR system and then reactants were continuously pumped into the reactor. This finding evidenced the strong sorption of both compounds onto the membrane. It was noted that, up to the moment of membrane breakthrough, the reaction volume was exchanged once (substrate) and three times (products). Moreover, the steady-state conditions were obtained after 16 (substrate) or 29 (products) volume exchanges. Thus, it was expected that the main problem could be to stabilize the concentrations of all reactants (enzyme, AB62, products) in the reaction device. Sorption of the product is a bottleneck in achieving steady-state conditions in the considered continuous process. Thus, the reaction rate could be stable after 6-7 h of the real reaction, which is equivalent to 30 times of the residence time. Fortunately, the membrane was permeable to AB62 and its oxidized products, although substantially more volume exchanges are required to obtain a steady-state regime than in conventional continuous systems (usually 4-5 times of the residence time).

\section{Kinetics of AB62 Decolorization with Laccase}

Prediction of the dye conversion in the continuous reactor is a critical issue. For this reason, a proper kinetic equation has to be selected and its parameters should be estimated. An enzyme immobilized in the volume of a membrane reactor provides a homogenous reaction system; therefore, kinetic parameters can be found using data from a batch reactor with a native enzyme. The interactions between AB62 and the enzyme were defined by the commonly used Eq. (3) (Fig. 6a; experimental points). However, in the case of AB62 decolorization, some deviations from a simple $1 / \mathrm{r}$ versus $1 / \mathrm{C}_{\mathrm{S} 0}$ dependence (Fig. $6 \mathrm{~b}$ ) were observed. These discrepancies are better visualized by the Eadie-Hofstee plot (Fig. 6c). Such behavior is attributed to the presence of multiple forms of the same enzyme (isoenzymes) that act on the same substrate but with different maximum reaction rates $\left(V_{\max (i)}\right)$ and/or Michaelis constants $\left(K_{\mathrm{m}(i)}\right)$ [40]. The obtained results confirmed data obtained by other authors, who 
(a)

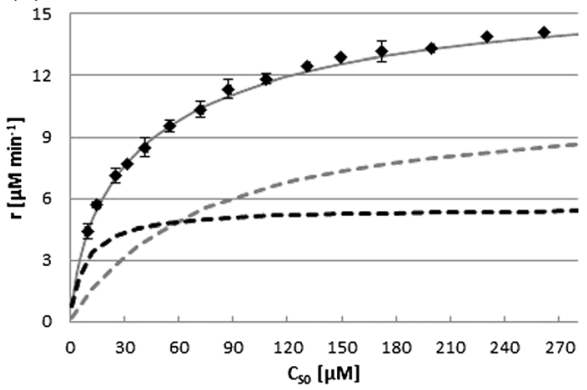

(c)

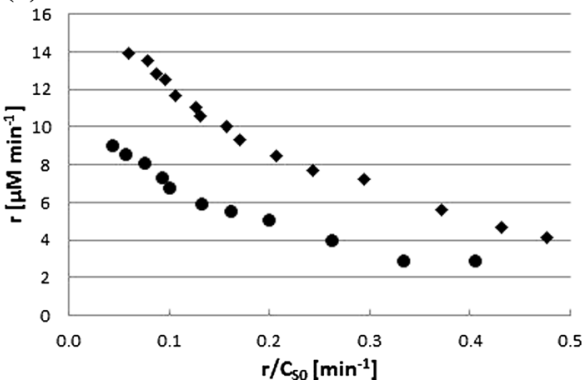

(b)

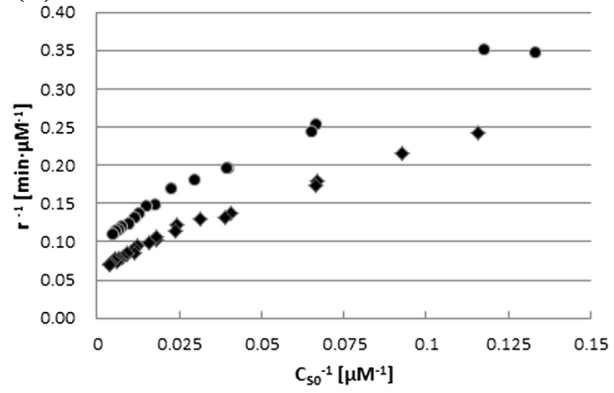

(d)

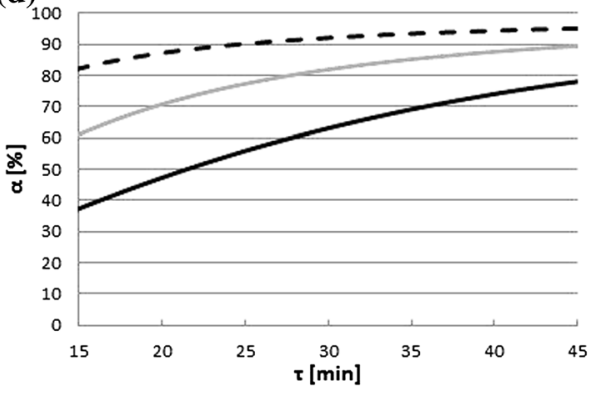

Fig. 6 Example of the effect of initial substrate concentration $\left(C_{\mathrm{S} 0}\right)$ on the initial reaction rate $(r)(\mathbf{a})$, Lineweaver-Burk plot (b), Eadie-Hofstee plot (c), and modeled (Eq. 5) variations of the conversion degree $(\alpha)$ with residence time $(\tau)$ (d). The solid line in a demonstrates the accuracy of the fitting of the experimental data to the isoenzyme model (Eq. 5) and the estimated parameters (Table 1). The dotted lines represent the hypothetical modeling for isoenzyme 1 (gray) and 2 (black). Reaction conditions: $\mathrm{pH} 5.3 ; 28{ }^{\circ} \mathrm{C}$; enzyme concentration in a $3.2 \mathrm{U}_{\mathrm{AB} 62} \mathrm{~mL}^{-1}\left(290 \mu \mathrm{g} \mathrm{L}^{-1}\right)$; in b and $\mathbf{c}$ (black diamond) $4.5 \mathrm{U}_{\mathrm{AB} 62} \mathrm{~mL}^{-1}\left(408 \mu \mathrm{g} \mathrm{L}^{-1}\right)$ and (white diamond) 3.2 $\mathrm{U}_{\mathrm{AB} 62} \mathrm{~mL}^{-1}\left(290 \mu \mathrm{g} \mathrm{L}^{-1}\right)$; in d $1.5 \mathrm{U}_{\mathrm{AB} 62} \mathrm{~mL}^{-1}$ - black solid line; $4.5 \mathrm{U}_{\mathrm{AB} 62} \mathrm{~mL}^{-1}$ - gray solid line; $12.0 \mathrm{U}_{\mathrm{AB} 62} \mathrm{~mL}^{-1}$ _black dashed line, $\left(136,408,1088 \mu \mathrm{g} \mathrm{L}^{-1}\right.$, respectively)

reported that the enzyme preparations from $C$. unicolor consist of two isoforms of laccase [35, 41]. In this case, the reaction rate at any substrate concentration is the sum of the velocities contributed by each isoform and is given by Eq. (5).

$$
r=r_{1}+r_{2}=\frac{V_{\max 1} \cdot C_{\mathrm{S} 0}}{K_{\mathrm{m} 1}+C_{\mathrm{S} 0}}+\frac{V_{\max 2} \cdot C_{\mathrm{S} 0}}{K_{\mathrm{m} 2}+C_{\mathrm{S} 0}}
$$

where the indexes 1 and 2 indicate the isoform number and

$$
V_{\max (i)}=C_{\mathrm{E}(i)} \cdot k_{\mathrm{cat}(i)}
$$

where $C_{\mathrm{E}}$ is the enzyme concentration.

Assuming that

$$
\mathrm{C}_{\mathrm{E}}=C_{\mathrm{E} 1}+C_{\mathrm{E} 2}
$$

where $C_{\mathrm{E} 1}$ and $C_{\mathrm{E} 2}$ are the concentration of enzyme isoforms 1 and 2, respectively; Eq. (5) has a form:

$$
r=\frac{k_{\mathrm{cat} 1} \cdot C_{\mathrm{E} 1} \cdot C_{\mathrm{S} 0}}{K_{\mathrm{m} 1}+C_{\mathrm{S} 0}}+\frac{k_{\mathrm{cat} 2} \cdot\left(C_{\mathrm{E}}-C_{\mathrm{E} 1}\right) \cdot C_{\mathrm{S} 0}}{K_{\mathrm{m} 2}+C_{\mathrm{S} 0}}
$$


Equation (5) allowed to estimate four kinetic parameters by means of nonlinear regression (Table 1). As seen, the $K_{\mathrm{m}}$ values for two different enzyme concentrations were similar what confirmed experimental accuracy. Moreover, fitting of the experimental points by the model (Fig. 6a) was very good. However, a simultaneous trial to determine all kinetic constants, $K_{\mathrm{m}(i)}, k_{\mathrm{cat}(i)}$ and the concentration of isoform $1\left(C_{\mathrm{E} 1}\right.$ in Eq. 7) failed due to the large number of parameters to be determined (Eq. 8). Hence, to limit the number of parameters to be estimated, the concentration of laccase isoforms was approximated from the ratio of the reaction rates of the isoforms $\left(r_{1}: r_{2}\right)$ for the infinite substrate concentration, based on the $V_{\max (i)}$ and $K_{\mathrm{m}(i)}$ parameters (Table 1). The calculated ratio was 1.85 and was independent of $C_{\mathrm{E}}$. Moreover, this value was reasonably similar to that presented by Michniewicz et al. [35] (1.48) what entitled us to calculate protein concentrations of both enzyme forms. Finally, the values of $k_{\text {cat } 1}$ and $k_{\text {cat2 } 2}$ were estimated using nonlinear regression with fixed Michaelis constants. The number of parameters that had to be determined (Table 1) in this operation was reduced to two. The very good confidence intervals demonstrated the mathematical correctness of the estimated constants.

Despite the same substrate, comparison of obtained values with those presented by other authors was very difficult (Table 2) and caused by different origins of laccases and/or their purity and process parameters $(\mathrm{pH}$, temperature). Even in the case of $C$. unicolor isoforms, a significant difference between the $k_{\text {cat }}$ constants was noted (rows 1 and 2 in Table 2), but this could be caused by the difference with the $\mathrm{pH}$ values used here and in the work by Michniewicz et al. [35], and by the enzyme purity. On the other hand, the $\mathrm{Km}$ values obtained for both isoforms here and in [35] appeared to be quite similar. Hence, it seems that the C. unicolor isoforms differ in enzyme-substrate affinities, whereas the reaction rate constants for both isoenzymes do not differ too much.

Finally, the possibility of product inhibition was examined. The initial reaction rates were measured in mixtures using a constant substrate concentration and product concentrations that ranged from 0 to $150 \mu \mathrm{g} \mathrm{L}^{-1}$. The laccase activity remained unchanged $\left(3.14 \pm 0.045 \mathrm{U}_{\mathrm{AB} 62} \mathrm{~mL}^{-1}\right)$. This finding led to the conclusion that there was no enzyme inhibition by the products of the AB62 oxidation and that the Eq. (8) should be sufficient to predict the variations in reaction rate with substrate concentrations for selected laccase concentration in a continuous-mode membrane reactor.

\section{Validation of the Kinetic Model in Continuous Decolorization in EMR}

The obtained kinetic parameters were used to plan processes and to verify their applicability to long-term AB62 decolorization. First, the value of the residence time $(\tau)$, that would allow an

Table 1 Kinetic parameters of AB62 decolorization by $C$. unicolor laccase

\begin{tabular}{|c|c|c|}
\hline \multirow[t]{2}{*}{ Parameter } & \multicolumn{2}{|c|}{ Enzyme concentration $\left(\mu \mathrm{g} \mathrm{L}^{-1}\right)$} \\
\hline & 290 & 408 \\
\hline$V_{\max 1}\left(\mu \mathrm{M} \min ^{-1}\right)$ & $7.37 \pm 1.07$ & $11.01 \pm 2.92$ \\
\hline$K_{\mathrm{m} 1}(\mu \mathrm{M})$ & $72.90 \pm 28.42$ & $67.99 \pm 32.87$ \\
\hline$V_{\max 2}\left(\mu \mathrm{M} \min ^{-1}\right)$ & $3.67 \pm 1.45$ & $5.14 \pm 3.46$ \\
\hline$K_{\mathrm{m} 2}(\mu \mathrm{M})$ & $5.64 \pm 3.40$ & $6.62 \pm 2.46$ \\
\hline$k_{\text {cat } 1}\left(\min ^{-1}\right)$ & $0.0331 \pm 0.0009$ & $0.0375 \pm 0.0011$ \\
\hline$k_{\text {cat } 2}\left(\min ^{-1}\right)$ & $0.0317 \pm 0.0008$ & $0.0351 \pm 0.0010$ \\
\hline
\end{tabular}


Table 2 Kinetic constants of the Michaelis-Menten equation for AB62 decolorization with laccases from different sources

\begin{tabular}{llllll}
\hline Microorganism & $\mathrm{pH}(-)$ & $T\left({ }^{\circ} \mathrm{C}\right)$ & $K_{\mathrm{m}}(\mu \mathrm{M})$ & $k_{\text {cat }}\left(\mathrm{s}^{-1}\right)$ & Reference \\
\hline Cerrena unicolor No. 139 & 5.3 & 30 & 6.22 & $38.5^{\mathrm{a}}$ & {$[$ here] } \\
& & & 74.11 & $41.8^{\mathrm{a}}$ & \\
Cerrena unicolor No. 137 & 3.5 & 25 & 42 & 366 & {$[35]$} \\
& & & 131 & 267 & \\
Trametes versicolor & 5.5 & 30 & 130 & 100 & {$[42]$} \\
Trametes versicolor & 4.5 & na & 305 & - & {$[43]$} \\
Trametes versicolor ATCC 32745 & 4.5 & na & 302 & 1373 & {$[43]$} \\
& & & 204 & 898 & \\
Phoma sp. UHH 5-1-03 & 4.0 & $\mathrm{RT}$ & $2844^{\mathrm{b}}$ & $32.2^{\mathrm{b}}$ & {$[44]$} \\
Phoma sp. UHH 5-1-03 & 4.5 & $\mathrm{na}$ & 194 & 34.1 & {$[43]$} \\
Bacillus subtilis & 4.5 & $\mathrm{na}$ & 165 & 3.1 & {$[43]$} \\
Pycnoporus sanguineus MUCL 41582 & 4.5 & na & 472 & 35.7 & {$[43]$} \\
Roglyr Lite $1540^{\mathrm{c}}$ & 4.7 & 25 & 90 & 45.5 & {$[45]$} \\
\hline
\end{tabular}

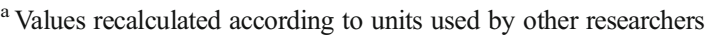

b Parameters derived from Hill's equation

${ }^{\mathrm{c}}$ Commercial product (Rotta Manheim)

$R T$ room temperature, na not available
}

assumed conversion degree $(\alpha)$ for specified initial substrate and enzyme concentrations (Eq. 8), was calculated from Eq. (9).

$$
r=\frac{\alpha \cdot C_{\mathrm{S} 0}}{\tau}=\frac{k_{\mathrm{cat} 1} \cdot C_{\mathrm{E} 1} \cdot C_{\mathrm{S} 0} \cdot(1-\alpha)}{K_{\mathrm{m} 1}+\cdot C_{\mathrm{S} 0} \cdot(1-\alpha)}+\frac{k_{\mathrm{cat} 2} \cdot C_{\mathrm{E} 2} \cdot C_{\mathrm{S} 0} \cdot(1-\alpha)}{K_{\mathrm{m} 2}+\cdot C_{\mathrm{S} 0} \cdot(1-\alpha)}
$$

Figure 6d represents examples of the modeled relationship of $\alpha$ vs. $\tau$ for selected laccase concentrations with the process parameters shown in Table 3 . In the first continuous process (Fig. 7a), a very low laccase activity and moderate residence time were applied. In such conditions, the substrate conversion should be not high, and any deviations from the expected values could be detected easily.

The aim of the first long-term process was to evaluate the applicability of the AB62 decolorization equation for the prediction of substrate conversion. This model did not take into account factors such as reagent sorption on the membrane surface, deactivation, and/ or unfavorable enzyme orientation after deposition on the membrane material. Table 3

Table 3 Verification of AB62 decolorization with laccase immobilized in the volume of the membrane reactor

\begin{tabular}{|c|c|c|c|c|}
\hline \multirow[t]{2}{*}{$C_{E}\left(\mu g L^{-1}\right)$} & \multirow[t]{2}{*}{ Parameter (-) } & \multicolumn{3}{|c|}{ Obtained values } \\
\hline & & Assumed & Experimental & Calculated (Eq. 9) \\
\hline \multirow[t]{2}{*}{136} & $\tau(\min )$ & 30 & $29.9 \pm 1.4$ & 29.9 \\
\hline & $\alpha(\%)$ & 65 & $60.0 \pm 5.3$ & 64.5 \\
\hline \multirow[t]{2}{*}{1088} & $\tau(\min )$ & 36 & $36.7 \pm 1.6$ & 34.2 \\
\hline & $\alpha(\%)$ & 94 & $98.3 \pm 0.9$ & 93.2 \\
\hline
\end{tabular}


(experimental and model values) shows that differences observed are statistically insignificant, although slightly lower conversion can be obtained in the experimental process. Most likely, the adsorption of laccase onto the membrane and/or the enzyme inactivation caused a decrease of the reaction rate. The entire process was conducted for $80 \mathrm{~h}$, during which the permeate flux decay was compensated by an increase of the transmembrane pressure (from 0.137 up to $0.188 \mathrm{MPa}$ ). The stable residence time (Fig. 7a) allowed us to conclude that the conversion gradient in permeate was originated from the laccase activity loss. Plotting the reaction rate values with time and using the semi-logarithm relationship (data not shown), it was found that the loss of laccase activity obeyed the first-order kinetics with a rate constant of $0.00367 \pm 0.00006 \mathrm{~h}^{-1}$.

The success in deriving the kinetic model to the prediction of the continuous process enabled us to run the next operation, in which $94 \%$ conversion was assumed. The permeate flux was set at a level for which it was easy to control the residence time (see Table 3). To achieve this goal, the enzyme concentration was increased eight times. Figure $7 \mathrm{~b}$ shows that
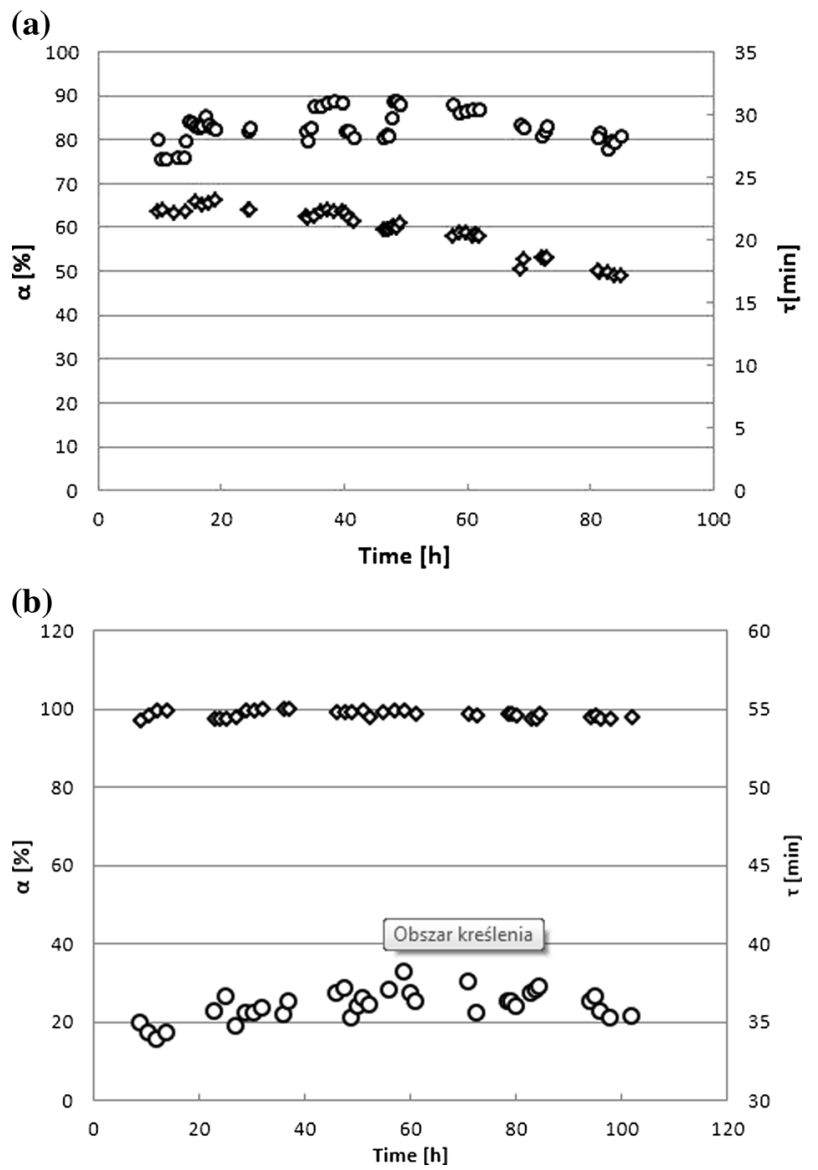

Fig. 7 AB62 decolorization with laccase immobilized in the EMR volume. White circle residence time; white diamond conversion degree. Data obtained in the first 7-h period were removed (unsteady-state conditions). Reaction conditions: $\mathrm{AB} 62$ concentration of $113.6 \mu \mathrm{M}$ in the feed; reactor volume of $50 \mathrm{~mL}$; $\mathrm{pH} 5.3 ; 30{ }^{\circ} \mathrm{C}$; enzyme concentration $1.5 \mathrm{U}_{\mathrm{AB} 62} \mathrm{~mL}^{-1}$ (a) and $12 \mathrm{U}_{\mathrm{AB} 62} \mathrm{~mL}^{-1}$ (b) 
residence time was stable and maintained by the increase of transmembrane pressure (from 0.137 up to $0.199 \mathrm{MPa}$ ); however, the ability to control the flux was limited at longer times. Interestingly, the laccase activity loss, that was visible in the first run of AB62 decolorization (Fig. 7a), was not observed in this case. Probably, the higher enzyme concentration increased the conformational stability of the protein what is a well-known phenomenon [46]. Therefore, a stable and very high substrate conversion $(98.3 \pm 0.866 \%)$ was achieved for more than $100 \mathrm{~h}$ continuous process. Comparing assumed substrate conversion and obtained in the experiment, significant statistical differences are noted (expected yield was of $94.8 \%$ of experimental yield). However, expected and experimental $\tau$ values differ similarly (93.2\%). Thus, although statistical differences are significant, they are proportional and that indicates some obstacles connected with polarization layer formed on the membrane.

Finally, we can compare our results with that obtained by other methods of AB62 decolorization [28-31]. In all the cases, substrate conversions were high, over $90 \%$. However, electrochemical degradation can be regarded as an energy-consuming process that demands long optimization of process conditions [1, 29]. In the case of absorption [28, 30], the main problem arises in the utilization of highly concentrated pollutant. Considering photocatalytic degradation over $\mathrm{CuO}-\mathrm{SnO}_{2}$ nanocomposite [31], a potential practical problem must be underlined; sunlight dependence excluded continuous process. Thus, laccase immobilized in the membrane reactor seems to be an energy-saving and environmentally safe solution for AB62 continuous decolorization.

\section{Conclusions}

It is obvious that any continuous process must be predictable. For that reason, isoenzyme model was applied, and on the base of derived parameters and the general equation for a continuous stirred tank reactor, the expected AB62 conversions were estimated and experimentally verified in the continuous processes. In the final process, the enzyme concentration and residence time were selected to obtain $94.0 \%$ substrate conversion. In this process, the conversion reached $98.3 \%$ and was stable for 4 days. Thus, the membrane reactor with C. unicolor laccase seems to be a very promising tool for AB62 decolorization.

Acknowledgments This study was supported by the project "Biotransformations for pharmaceutical and cosmetics industry" No. POIG.01.03.01-00-158/09-09 partly financed by the European Union within the European Regional Development Fund under Operational Program Innovative Economy.

Open Access This article is distributed under the terms of the Creative Commons Attribution 4.0 International License (http://creativecommons.org/licenses/by/4.0/), which permits unrestricted use, distribution, and reproduction in any medium, provided you give appropriate credit to the original author(s) and the source, provide a link to the Creative Commons license, and indicate if changes were made.

\section{References}

1. Robinson, T., McMullan, G., Marchant, R., \& Nigam, P. (2001). Remediation of dyes in textile effluent: a critical review on current treatment technologies with a proposed alternative. Bioresource Technology, 77, 247-255.

2. Slokar, Y. M., \& Majcen Le Marechal, A. (1998). Methods for decolorization textile wastewaters. Dyes and Pigments, 37, 365-356. 
3. Forgacs, E., Cserhati, T., \& Oros, G. (2004). Removal of synthetic dyes from wastewaters: a review. Environment International, 30, 953-971.

4. Rai, H. S., Bhattacharya, M. S., Singh, J., Bansal, T. K., Vats, P., \& Banerjee, U. C. (2005). Removal of dyes from the effluent of textile and dyestuff manufacturing industry: a review of emerging techniques with reference to biological treatment. Critical Reviews in Environmental Science and Technology, 35, 219-238.

5. Kulikova, N. A., Klein, O. I., Stepanova, E. V., \& Koroleva, O. V. (2011). Use of Basidiomycetes in industrial waste processing and utilization technologies: fundamental and applied aspects (review). Applied Biochemistry and Microbiology, 47, 565-579.

6. Madhavi, V., \& Lele, S. S. (2009). Laccase: properties and application. BioResources, 4, 1694-1717.

7. Mukherjee, S., Basak, B., Bhunia, B., Dey, A., \& Mondal, B. (2013). Potential use of polyphenol oxidases (PPO) in the bioremediation of phenolic contaminants containing industrial wastewater. Reviews in Environmental Science and Biotechnology, 12, 61-73.

8. Dos Santos, A. B., Cervantes, F. J., \& Van Lier, J. B. (2007). Review paper on current technologies for decolourisation of textile wastewaters: perspectives for anaerobic biotechnology. Bioresource Technology, 98, 2369-2385.

9. Alaton, I. A., Balcioglu, I. A., \& Bahnemann, D. W. (2002). Advanced oxidation of a reactive dyebath effluent: comparison of $\mathrm{O}_{3}, \mathrm{H}_{2} \mathrm{O}_{2} / \mathrm{UV}-\mathrm{C}$ and $\mathrm{TiO}_{2} / \mathrm{UV}$-a processes. Water Research, 36, 1143-1154.

10. Chang, S. H., Wang, K. S., Chao, S. J., Peng, T. H., \& Huang, L. C. (2009). Degradation of azo and anthraquinone dyes by a low-cost Fe0/air process. Journal of Hazardous Materials, 166, $1127-1136$.

11. Moussavi, G., \& Mahmoudi, M. (2009). Removal of azo and anthraquinone reactive dyes from industrial wastewaters using MgO nanoparticles. Journal of Hazardous Materials, 168, 806-812.

12. Forss, J., \& Welander, U. (2011). Biodegradation of azo and anthraquinone dyes in continuous systems. International Biodeterioration \& Biodegradation, 65, 227-237.

13. Jiang, M., Ten, Z., \& Ding, S. (2013). Decolorization of synthetic dyes by crude and purified laccases from Coprinus comatus grown under different cultures: the role of major isoenzyme in dyes decolorization. Applied Biochemistry and Biotechnology, 169, 660-672.

14. Chairin, T., Nitheranont, T., Watanabe, A., Asada, Y., Khanongnuch, C., \& Lumyong, S. (2013). Biodegradation of bisphenol A and decolorization of synthetic dyes by laccase from white-rot fungus, Trametes polyzona. Applied Biochemistry and Biotechnology, 169, 539-545.

15. Celebi, M., Kaya, M. A., Altikatoglu, M., \& Yildirim, H. (2013). Enzymatic decolorization of anthraquinone and diazo dyes using horseradish peroxidase enzyme immobilized onto various polysulfone supports. Applied Biochemistry and Biotechnology, 171, 716-730.

16. Li, H. X., Zhang, R. J., Tang, L., Zhang, J. H., \& Mao, Z. G. (2014). In vivo and in vitro decolorization of synthetic dyes by laccase from solid state fermentation with Trametes sp. SYBC-L4. Bioprocess and Biosystems Engineering, 37, 2597-2605.

17. Sarayu, K., \& Sandhya, S. (2012). Current technologies for biological treatment of textile wastewater-a review. Applied Biochemistry and Biotechnology, 167, 645-661.

18. Padmanaban, V. C., Prakash, S. S., Sherildas, P., Jacob, J. P., \& Nelliparambil, K. (2013). Biodegradation of anthraquinone based compounds: review. International Journal of Advanced Research Engineering Technology, 4, 74-83.

19. Mazzei, R., Drioli, E., \& Giorno, L. (2010). Biocatalytic membranes and membrane bioreactors, in comprehensive membrane science and engineering, vol. 3. In E. Drioli, \& L. Giorno (Eds.), Chemical and biochemical transformations in membrane systems. Amsterdam: Elsevier B.V.

20. Jochems, P., Satyawali, Y., Diels, L., \& Dejonghe, A. (2011). Enzyme immobilization on/in polymeric membranes: status, challenges and perspectives in biocatalytic membrane reactors (BMRs). Green Chemistry, 13, 1609-1623.

21. Chhabra, M., Mishra, S., \& Sreekrishnan, T. R. (2009). Laccase/mediator assisted degradation of triarylmethane dyes in a continuous membrane reactor. Journal of Biotechnology, 143, 69-78.

22. Katuri, K. P., Mohan, S. V., Sridhar, S., Pati, B. R., \& Sarma, P. N. (2009). Laccase-membrane reactors for decolorization of an acid azo dye in aqueous phase: process optimization. Water Research, 43, 3647-3658.

23. Mendoza, L., Jonstrup, M., Hatti-Kaula, R., \& Mattiasson, B. (2011). Azo dye decolorization by a laccase/ mediator system in a membrane reactor: enzyme and mediator reusability. Enzyme and Microbial Technology, 49, 478-484.

24. Lopez, C., Moreira, M. T., Feijoo, G., \& Lema, J. M. (2007). Dynamic modeling of an enzymatic membrane reactor for the treatment of xenobiotic compounds. Biotechnology and Bioengineering, 97, 1128-1137.

25. Vasic-Racki, D., Bongs, J., Schorken, U., Sprenger, G. A., \& Liese, A. (2003). Modeling of reaction kinetics for reactor selection in the case of L-erythrulose synthesis. Bioprocess and Biosystems Engineering, 25, 285-290. 
26. Pereira, L., Coelho, A. V., Viegas, C. A., Ganachaud, C., Iacazio, G., Tron, T., Robalo, M. P., \& Martins, L. O. (2009). On the mechanism of biotransformation of the anthraquinonic dye acid blue 62 by laccases. Advanced Synthesis and Catalysis, 351, 1857-1865.

27. Bryjak, J., \& Rekuć, A. (2010). Effective purification of Cerrena unicolor laccase using microfiltration, ultrafiltration and acetone precipitation. Applied Biochemistry and Biotechnology, 160, 2219-2235.

28. Alkan, M., Celikcapa, S., Demirbas, O., \& Dogan, M. (2005). Removal of reactive blue 221 and acid blue 62 anionic dyes from aqueous solutions by sepiolite. Dyes and Pigments, 65, 251-259.

29. Aquino, J. M., Rocha, R. C., Bocchi, N., \& Biaggio, S. R. (2010). Electrochemical degradation of the acid blue 62 dye on a beta-PbO2 anode assessed by the response surface methodology. Journal of Applied Electrochemistry, 40, 1751-1757.

30. Russo, M. E., Di Natale, F., Prigione, V., Tigini, V., Marzocchella, A., \& Varese, G. C. (2010). Adsorption of acid dyes on fungal biomass: equilibrium and kinetics characterization. Chemical Engineering Journal, 162, 537-545.

31. Xia, H. L., Zhuang, H. S., Zhang, T., \& Xiao, D. C. (2007). Photocatalytic degradation of acid blue 62 over $\mathrm{CuO}-\mathrm{SnO} 2$ nanocomposite photocatalyst under simulated sunlight. Journal of Environmental Sciences, 19 , 1141-1145.

32. Sanchez-Lopez, M. I., Vanhulle, S., Mertens, V., Guerra, G., Figueroa, S. H., Decock, C., Corbisier, A. M., \& Penninckx, M. J. (2008). Autochthonous white rot fungi from the tropical forest: potential of Cuban strains for dyes and textile industrial effluents decolourisation. African Journal of Biotechnology, 7, 1983-1990.

33. Vanhulle, S., Enaud, E., Trovaslet, M., Nouaimeha, N., Bols, C. M., Keshavarz, T., Tron, T., Sannia, G., \& Corbisier, A. M. (2007). Overlap of laccases/cellobiose dehydrogenase activities during the decolourisation of anthraquinonic dyes with close chemical structures by Pycnoporus strains. Enzyme and Microbial Technology, 40, 1723-1731.

34. Vanhulle, S., Enaud, E., Trovaslet, M., Billottet, L., Kneipe, L., Jiwan, J. L. H., Corbisier, A. M., \& Marchand-Brynaert, J. (2008). Coupling occurs before breakdown during biotransformation of acid blue 62 by white rot fungi. Chemosphere, 70, 1097-1107.

35. Michniewicz, A., Ledakowicz, S., Ullrich, R., \& Hofrichter, M. (2008). Kinetics of the enzymatic decolorization of textile dyes by laccase from Cerrena unicolor. Dyes and Pigments, 77, 295-302.

36. Lowry, O. H., Rosenbrough, N. J., Farr, A. L., \& Randall, R. J. (1951). The Journal of Biological Chemistry, 193, 265-275.

37. Dunn, I. J., Heinzle, E., Ingham, J., \& Prenosil, J. E. (1992). Biological reaction engineering: principles, applications and modeling with PC simulation. Weinheim: $\mathrm{VCH}$.

38. Rekuć, A., Jastrzembska, B., Liesiene, J., \& Bryjak, J. (2009). Comparative studies on immobilized laccase behavior in packed-bed and batch reactors. Journal of Molecular Catalysis B: Enzymatic, 57, 216-223.

39. Lewańczuk, M., Fedczuk, B., \& Bryjak, J. (2013). Reactive blue 81 decolorization by laccase in a membrane reactor. PhD Interdiscip Journal, 1, 47-53.

40. Rios, G. M., Belleville, M. P., Paolucci, D., \& Sanchez, J. (2004). Progress in enzymatic membrane reactors - a review. Journal of Membrane Science, 242, 189-196.

41. Michniewicz, A., Ullrich, R., Ledakowicz, S., \& Hofrichter, M. (2006). The white-rot fungus Cerrena unicolor strain 137 produces two laccase isoforms with different physico-chemical and catalytic properties. Applied Microbiology and Biotechnology, 69, 682-688.

42. Enaud, E., Trovaslet, M., Naveau, F., Decristoforo, A., Bizet, S., Vanhulle, S., \& Jolivalt, C. (2011). Laccase chloride inhibition reduction by an anthraquinonic substrate. Enzyme and Microbial Technology, 49, 517-525.

43. Trovaslet, M., Enaud, E., Bazes, A., Jolivalt, C., Van Hove, F., \& Vanhulle, S. (2008). Laccase-catalyzed azodye synthesis. Naples:Industrial Biotechnology International Conference.

44. Junghanns, C., Pecyna, M. J., Bohm, D., Jehmlich, N., Martin, C., von Bergen, M., Schauer, F., Hofrichter, M., \& Schlosser, D. (2009). Biochemical and molecular genetic characterization of a novel laccase produced by the aquatic ascomycete. Applied Microbiology and Biotechnology, 84, 1095-1105.

45. Stanescu, M. D., Stanislav, A., Ivanov, R. V., Hirtopeanu, A., \& Lozinsky, V. I. (2011). Immobilized laccase on a new cryogel carrier and kinetics of two anthraquinone derivatives oxidation. Applied Biochemistry and Biotechnology, 165, 1789-1798.

46. Guo, J., Harn, N., Robbins, A., Dougherty, R., \& Middaugh, R. C. (2006). Stability of helix-rich proteins at high concentrations. Biochemistry, 45, 8686-8696. 